Objectives: To explore the status of the immunologic balance between Th17 cells and Treg cells in patients with SPA, and to assess the effect of low dose IL-2 on the peripheral $\mathrm{CD} 4+\mathrm{T}$ cells

Methods: Two hundred and two patients, who met the Assessment of Spondyloarthritis International Society (ASAS) criteria were enrolled and given conventional therapy, including Nonsteroidal Anti-inflammatory Drugs (NSAIDs), biological agents, Sulfasalazine, glucocorticoid. Eighty seven patients were not only given conventional therapy, but also injected subcutaneously low-dose IL-2 (50 WIU/day for 5 days). Clinical and laboratory indicators were compared before and after IL-2 treatment. The CD4 ${ }^{+} \mathrm{T}$ cells in peripheral blood were measured by multicolor flow cytometry. The side effects were observed in the course of therapy. Results: The absolute number and ratio of CD4 + CD25 + FOXp3 + regulatory T cells in peripheral blood of patients with SPA was significantly decreased compared with the healthy control group, $(25.13(18.76,37.37)$ vs. $33.06(22.87,42.33)$, $\mathrm{P}<0.001)$; Th17/Treg $(0.29(0.18,0.49)$ vs. $0.20(0.15,0.34), P=0.001)$. The absolute number of Treg cells increased more than 3-times $(22.70(14.47,30.10)$ vs.67.87 (48.21, 105.82), $\mathrm{p}<0.001)$ after 5 days of low-dose IL-2 treatment. Th17/Treg was significantly higher $(0.32(0.18,0.57)$ vs. $0.20(0.15,0.34)$, $\mathrm{P}<0.001)$ before treatment compared with healthy controls.

Conclusions: The decrease of CD4 + CD25 + FOXp3 + Treg cells might play a key role in the pathogenesis of SpA. Low dose IL-2 therapy can restore and maintain the balance of Th17 and Treg cells by increasing Treg cells numbers selectivity. The therapy is safe. More attention should be paid on the long term benefits of low-dose IL-2 therapy in the further research.

References:

[1] Wu Y, Ren M, Yang R, Liang X, Ma Y, Tang Y, et al. Reduced immunomodulation potential of bone marrow-derived mesenchymal stem cells induced CCR4 + CCR6 + Th/Treg cell subset imbalance in ankylosing spondylitis. Arthritis Res Ther. 2011;13:R29.

[2] Jandus C, Bioley G, Rivals JP, Dudler J, Speiser D, Romero P. Increased numbers of circulating polyfunctional Th17 memory cells in patients with seronegative spondylarthritides. Arthritis Rheum. 2008;58:2307-17.

[3] Wendling D, Guillot X, Prati C. The IL-23/Th 17 pathway in spondyloarthritis: the royal road. Joint Bone Spine 82(1), 1-4 (2015)

Disclosure of Interest: None declared

DOI: 10.1136/annrheumdis-2017-eular.2648

\section{THU0378 IMPACT OF THE ADALIMUMAB PATIENT SUPPORT PROGRAM ON CLINICAL OUTCOMES IN ANKYLOSING SPONDYLITIS: RESULTS FROM THE COMPANION STUDY}

L. Bessette ${ }^{1}$, C. Thorne ${ }^{2}$, B. Millson ${ }^{3}$, K. Charland ${ }^{3}$, K. Donepudi ${ }^{3}$ T. Gaetano ${ }^{4}$, V. Remple ${ }^{4}$, M. Latour ${ }^{4}$, M.-C. Laliberté ${ }^{4}$. ${ }^{1}$ Department of Medicine, Laval University, Quebec City; ${ }^{2}$ Southlake Regional Health Centre, Newmarket: ${ }^{3}$ QuintilesIMS, Kirkland: ${ }^{4}$ AbbVie Corporation, St. Laurent, Canada

Background: Adalimumab (ADL) is a TNF-alpha inhibitor indicated for various inflammatory autoimmune diseases including ankylosing spondylitis (AS). Patients receiving $A D L$ in Canada are eligible to enroll in the AbbVie Care patient support program (PSP) which provides them with personalized services including ongoing care coach calls (CCC). In a previous study, rheumatology patients enrolled in Abbvie Care receiving CCC demonstrated significantly greater persistence and adherence to ADL than patients that did not receive CCC (no-CCC).

Objectives: The objective of this study was to examine if $A D L$ patients receiving CCC through the ADL PSP had an increased likelihood of achieving controlled disease state as determined by a Bath Ankylosing Spondylitis Disease Activity Index (BASDAl) score $<4$ compared to those not receiving CCC.

Methods: A longitudinal analysis using de-identified aggregate-level data collected through the AbbVie Care PSP was performed. Probabilistic matching was used to link patient-level records from the ADL PSP database to records from the QuintilesIMS longitudinal prescription transactions database (LRx). Patients were indexed on the date of their first ADL transaction between January 2010 and October 2015. The ADL PSP database included patient measurements of the BASDAI, a measure of disease activity. To be eligible, patients had to have a baseline BASDAI measurement between 90 days before and 30 days after their index date and have had a follow-up BASDAl measurement 6 to 18 months later. Only patients that were confirmed to be persistent on ADL as confirmed through the $L R x$ records were included in the comparison. Controlled disease (BASDAI $<4)$ at the time of the follow-up BASDAI assessment was compared in patients having received CCC and patients without CCC. Robust Poisson regression was used to estimate the adjusted relative risk (RR) of controlled disease. Analyses were adjusted for patient age group, sex, region, prior biologic use, days lapsed between BASDAI assessments, and baseline disease control status category. Results: A total of 249 AS patients met eligibility criteria and $123(49 \%)$ of these had received CCC. Of the 249 patients, $184(74 \%)$ had controlled disease (BASDAI <4) at the follow-up assessment, $98(80 \%)$ in the CCC group and 86 $(68 \%)$ in the no CCC group. In the multivariable regression analysis, there was a $23 \%$ increased likelihood of achieving controlled disease in the CCC group relative to the group without CCC ( $R R=1.23,95 \%$ confidence interval: 1.06-1.42; p-value $=0.0055$.

Conclusions: AS patients receiving tailored services through the ADL PSP in the form of care coach calls have an increased likelihood of achieving controlled disease within 6 to 18 months. These results may help refine interventions aiming at improving clinical outcomes in AS patients.

Acknowledgements: Project management support for this study was provided by Jennifer Glass from QuintilesIMS. Analytical support was provided by Marc Duclos from QuintilesIMS. This support was funded by AbbVie.

Disclosure of Interest: L. Bessette Grant/research support from: Abbvie, Amgen, BMS, Janssen, Roche, UCB, Pfizer, Merck, Celgene, Sanofi, Lilly, Novartis, Consultant for: AbbVie, Amgen, BMS, Janssen, Roche, UCB, Pfizer, Celgene, Lilly, Novartis, Speakers bureau: AbbVie, Amgen, BMS, Janssen, Roche, UCB, Pfizer, Merck, Celgene, Lilly, Novartis, C. Thorne Grant/research support from: Abbvie, Amgen, Celgene, CaREBiodam, Lilly, Novartis, Pfizer, Consultant for: AbbVie, Amgen, Celgene, Centocor, Genzyme, Hospira, Janssen, Lilly, Medexus/Medac, Merck, Novartis, Pfizer, Sanofi, Speakers bureau: Medexus/Medac, B. Millson Consultant for: AbbVie, Employee of: QuintilesIMS, K. Charland Consultant for: AbbVie, Employee of: QuintilesIMS, K. Donepudi Consultant for: AbbVie, Employee of: QuintilesIMS, T. Gaetano Shareholder of: AbbVie, Employee of: AbbVie, V. Remple Shareholder of: AbbVie, Employee of: AbbVie, M. Latour Shareholder of: AbbVie, Employee of: AbbVie, M.-C. Laliberté Shareholder of: AbbVie, Employee of: AbbVie

DOI: 10.1136/annrheumdis-2017-eular.6529

\section{THU0379 IMPACT OF TIME SINCE DIAGNOSIS, AGE, AND NUMBER OF PRIOR NON-STEROIDAL ANTI-INFLAMMATORY DRUGS ON 52-WEEK CLINICAL RESPONSE TO ADALIMUMAB IN PATIENTS WITH ANKYLOSING SPONDYLITIS}

J. Sieper ${ }^{1}$, A. Deodhar ${ }^{2}$, M. Hoinik ${ }^{3}$, Y. Zhang ${ }^{4}$, M. Dougados ${ }^{5} .{ }^{1}$ Charité $^{2}$ Universitätsmedizin Berlin, Berlin, Germany; ${ }^{2}$ Oregon Health \& Science University, Portland, United States; ${ }^{3}$ AbbVie, Ljubljana, Slovenia; ${ }^{4}$ AbbVie Inc., $N$ Chicago, United States; ${ }^{5}$ René Descartes University and Hôpital Cochin, Paris, France

Background: Ankylosing spondylitis (AS) patients (pts) were found to respond better to TNF inhibitors (TNFi) if treated early in the disease course. ${ }^{1}$ The actual disease onset and hence disease duration is not always known. Previously, younger age was found to have the largest positive impact on clinical outcomes following 12 weeks (wks) of adalimumab (ADA) treatment. ${ }^{2}$

Objectives: The objective of this analysis was to examine the impact of time since diagnosis, age, and number of prior NSAIDs as surrogates for disease duration on clinical outcomes in AS pts from ATLAS trial treated with ADA for 52 wks.

Methods: ATLAS $^{3,4}$ was a phase 3 randomized double-blind placebo (PBO)controlled trial evaluating the safety and efficacy of originator ADA in pts with active AS who failed NSAID therapy. In this post hoc analysis, pts who received at least one dose of ADA during the PBO-controlled period or open label extension and received prior NSAID(s) at baseline (BL) were categorized by BL: (1) time since diagnosis ( $<2$ vs $\geq 2 ;<5$ vs $\geq 5 ;<10$ vs $\geq 10$ years [y]), (2) age $(<35$, $35-45$, and $>45 \mathrm{y}$ ), and (3) number of prior NSAIDs $(\leq 2 \mathrm{vs}>2$ ). The effect of time since diagnosis, age, and number of prior NSAIDs on AS outcome measures following 52 wks of ADA treatment was examined.

Results: At wk 52, 274 pts had received at least one dose of ADA and had at least one prior NSAID at BL. A majority of pts were $\geq 5$ y since AS diagnosis (188 [68.6\%]), $\leq 45 \mathrm{y}$ of age $(163[59.5 \%])$, HLA-B27+ (213 [77.7\%]), and had $\leq 2$ prior NSAIDs (158 [57.7\%]). Pts with shorter time since diagnosis were generally younger (late thirties). Across all subcategories, $>70 \%$ of pts were male. The BL disease activity measures were numerically similar across most categories. Following 52 wks of ADA treatment, the proportions of pts achieving ASAS20 and ASAS40 responses were numerically higher and mean decreases in BASDAI and BASFI scores from BL larger in subcategories with shorter time since diagnosis, younger age, and fewer prior NSAIDs (Table). There were significant differences in ASAS40, BASDAl, and BASFI scores between time since diagnosis ( $<2$ vs $\geq 2$ and $<5$ vs $\geq 5 \mathrm{y})$ and age ( $<35$ vs $>45 \mathrm{y})$ subcategories.

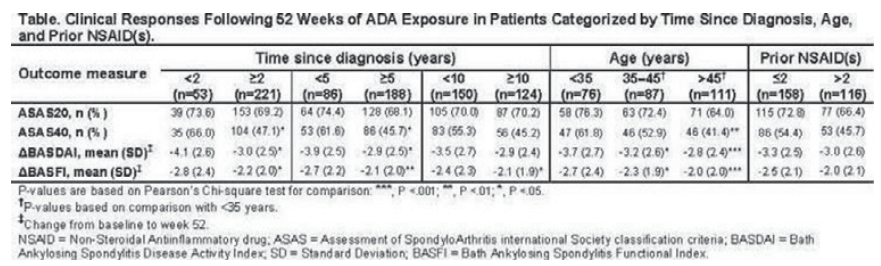

Conclusions: Following 52 wks of ADA treatment, shorter time since diagnosis and younger age were associated with greater clinical responses and improvements in disease activity and functionality. Although younger age ( $<35$ vs $>45$ y) had significant positive impact on the clinical outcomes similar to wk 12 results, shorter time since diagnosis ( $<2$ vs $\geq 2$ and $<5$ vs $\geq 5$ y) was also associated with better 52 -wk clinical outcomes. These results suggest that early effective treatment intervention may improve long-term clinical outcomes in AS pts.

References:

[1] Rudwaleit, M. et al. Ann Rheum Dis, 2004; 63:665-70.

[2] Sieper, J. et al., Arthritis Rheumatol. 2016; 68 (suppl 10).

[3] Van der Heijde, D. et al., Ann Rheum Dis, 2007; 67:1218-21. 
[4] Sieper, J. et al., Ann Rheum Dis, 2012; 71:700-6.

Acknowledgements: AbbVie funded the study (NCT00085644), contributed to its design, and participated in data collection, analysis and interpretation of the data, and in writing, review, and approval of the publication. Medical writing support was provided by Deepa Venkitaramani, PhD, of AbbVie.

Disclosure of Interest: J. Sieper Grant/research support from: AbbVie, Lilly, Janssen, Merck, Novartis, Pfizer, Roche, Sun Pharma, and UCB, Consultant for: AbbVie, Lilly, Janssen, Merck, Novartis, Pfizer, Roche, Sun Pharma, and UCB, Speakers bureau: AbbVie, Lilly, Janssen, Merck, Novartis, Pfizer, Roche, Sun Pharma, and UCB, A. Deodhar Grant/research support from: AbbVie, Amgen, Eli Lilly, Glaxo-Smith-Kline, Merck-Sharp-Dohme, Novartis, Pfizer, Sun Pharma, and UCB, Consultant for: AbbVie, Amgen, Eli Lilly, Glaxo-Smith-Kline, Merck-Sharp-Dohme, Novartis, Pfizer, Sun Pharma, and UCB, Speakers bureau: AbbVie, Amgen, Eli Lilly, Glaxo-Smith-Kline, Merck-Sharp-Dohme, Novartis, Pfizer, Sun Pharma, and UCB, M. Hojnik Shareholder of: AbbVie, Employee of: AbbVie, Y. Zhang Shareholder of: AbbVie, Employee of: AbbVie, M. Dougados Grant/research support from: AbbVie, Lilly, Merck, Novartis, Pfizer, Sanofi, and UCB, Consultant for: AbbVie, Lilly, Merck, Novartis, Pfizer, Sanofi, and UCB, Speakers bureau: AbbVie, Lilly, Merck, Novartis, Pfizer, Sanofi, and UCB DOI: 10.1136/annrheumdis-2017-eular.1302

\section{THU0380 RESULTS OF A REAL LIFE DOSE-REDUCTION STRATEGY FOR ANTI-TNFALPHA INHIBITORS IN A COHORT OF PATIENTS WITH SPONDYLOARTHRITIS}

M.C. Castro-Villegas ${ }^{1,2}$, P. Font-Ugalde ${ }^{1,2,3}$, M. Romero-Gomez ${ }^{1,2}$, M. Arredondo-López ${ }^{3}$, E.C. López-Medina ${ }^{1}$, R. Ortega-Castro ${ }^{1,2}$,

J. Calvo-Gutierrez ${ }^{1,2,3}$, A. Escudero-Contreras ${ }^{1}$, E. Collantes-Estévez ${ }^{1,2,3}$

${ }^{1}$ Reina Sofía University Hospital; ${ }^{2}$ IMIBIC; ${ }^{3}$ Universidad de Córdoba, Cordoba, Spain

Background: Published reports suggest that patients with Spondyloartrhitis $(\mathrm{SpA})$ in remission under treatment with TNFalpha inhibitors (TNFi) could obtain the same benefit at lower dose of the drug.

Objectives: To evaluate effectiveness of a strategy of dose reduction of TNFi in SpA patients in clinical remission and to explore baseline characteristics predictive of maintenance of the response.

Methods: Retrospective observational study, including patients with SpA meeting ASAS criteria treated with TNFi following a dose optimization protocol (lower doses or longer intervals than aproved), from 2008 to 2015. Criteria for optimization was patients with $B A S D A I<2$ and/or $C$ reactive protein level $(C R P) \leq 5 \mathrm{mg} / \mathrm{L}$ for at least 6 months. Patients who relapsed (BASDAl $>2$ and/or $C R P>5 \mathrm{mg} / \mathrm{L}$ ) returned to standard dose. Clinical/analytical parameters and drug's survival time until relapse were recorded. SPSSv.17 software was used for contrast means. Survival Kaplan-Meyer curves was analysed.

Results: 149 SpA patients treated with TNFi, 32/149 patients (21.5\%) included in optimization protocol. 27 patients $(84.37 \%)$ with increased interval between doses, remaining with reduced dosification. Table 1 shows baseline characteristics of patients on optimization group (mean $\pm S D$ or proportion). 18/32 patients (56.2\%,IC:39.01-73.4) maintained clinical remission with optimized dose at 36.5 months (median). Table 2 shows activity parametres of both relapsed and maintained response patients. There were either baseline differences or at optimization time between patients who maintained remission and not, but relapsed patients showed higher CRP at optimization time, without statistically significant differences. $72.2 \%(13 / 18)$ of patients on sutained remission were naive for TNFi, although no significant difference compared to switcher patients on the median survival (31.9 vs 20.9 months, $P=0.9$ ). No baseline predictor of

Table 1

\begin{tabular}{|c|c|c|}
\hline & \multicolumn{2}{|c|}{ Optimized patients ( $n=32)$} \\
\hline Age (years) & \multicolumn{2}{|c|}{$47.2 \pm 10.6$} \\
\hline Gender (\%) Male/Female & \multicolumn{2}{|c|}{$84.4 / 15.6$} \\
\hline \multirow[t]{2}{*}{ Disease duration (years) } & \multicolumn{2}{|c|}{$12.2 \pm 10.4$} \\
\hline & Baseline & Optimization time \\
\hline BASDAI (0-10) & $4.2 \pm 2,6$ & $2.1 \pm 2.2$ \\
\hline BASFI $(0-10)$ & $4 \pm 2.7$ & $2.8 \pm 2.9$ \\
\hline $\operatorname{ESR}\left(\mathrm{mm} / 1^{\circ} \mathrm{h}\right)$ & $19 \pm 20.1$ & $8.5 \pm 8.5$ \\
\hline $\mathrm{CRP}(\mathrm{mg} / \mathrm{L})$ & $13.1 \pm 18.7$ & $6.4 \pm 9.7$ \\
\hline Number of previous TNFi & \multicolumn{2}{|c|}{$0.3 \pm 0.6$} \\
\hline \multicolumn{3}{|l|}{ Current TNFi (\%) } \\
\hline Infliximab & \multicolumn{2}{|c|}{$31.3 \%$} \\
\hline Adalimumab & \multicolumn{2}{|c|}{$21.9 \%$} \\
\hline Etanercept & \multicolumn{2}{|c|}{$25 \%$} \\
\hline Golimumab & \multicolumn{2}{|c|}{$21.9 \%$} \\
\hline
\end{tabular}

Table 2

\begin{tabular}{|c|c|c|c|c|c|c|}
\hline & \multicolumn{3}{|c|}{ Not-sustained remission $(n=14)$} & \multicolumn{3}{|c|}{ Sustained Remission $(n=18)$} \\
\hline & Basaline & Optimization time & Flare time & Basaline & Optimization time & Last visit \\
\hline & $3.8 \pm 2.4$ & & $2.4 \pm 1$ & & & \\
\hline & & & & & & \\
\hline & & & & & & $8 \pm 6$ \\
\hline $\mathrm{CRP}(\mathrm{mg} / \mathrm{L})$ & $10.9 \pm 12.2$ & $9.7 \pm 12.4$ & $3.4 \pm 5.7^{\star \#}$ & $14.6 \pm 22.5$ & $3.7 \pm 6.1^{*}$ & $2.5 \pm 5^{*}$ \\
\hline
\end{tabular}

Statistical significant differences: ${ }^{*}$ compare to baseline; ${ }^{*}$ compared to optimization time. sustained response at optimized dose were found. CRP $<5 \mathrm{mg} / \mathrm{L}$ at optimization time showed a trend towards longer survival (43.4 vs 13.3 months), without differences statistically significant $(\mathrm{p}=0.09)$.

Conclusions: Optimization of TNFi in SpA is possible and allows up to half of patients to maintain clinical remission, but no baseline factors predictors of sustained response after optimization was found.

Disclosure of Interest: None declared

DOI: 10.1136/annrheumdis-2017-eular.2633

\section{THU0381 CERTOLIZUMAB PEGOL IS EFFECTIVE IN UVEITIS ASSOCIATED TO SPONDYLOARTHRITIS REFRACTORY TO OTHER TUMOUR NECROSIS FACTOR INHIBITORS}

M.V. Hernández ${ }^{1}$, M. Mesquida ${ }^{2}$, V. Llorens ${ }^{2}$, M. Sainz de la Maza ${ }^{2}$, R. Blanco ${ }^{3}$, V. Calvo ${ }^{3}$, O. Maiz ${ }^{4}$, A. Blanco ${ }^{5}$, A. Urruticoechea ${ }^{6}$, J.R.D.D. Jiménez de Aberásturi ${ }^{7}$, P. Ahijado ${ }^{8}$, E. Judez ${ }^{9}$, P. Tejón ${ }^{10}$, S. Peña ${ }^{11}$, A. Adan ${ }^{2}$, R. Sanmartí ${ }^{1} \cdot{ }^{1}$ Rheumatology; ${ }^{2}$ Ophtalmology, Hospital Clínic, Barcelona; ${ }^{3}$ Rheumatology, Hospital Marqués de Valdecilla, Santander; ${ }^{4}$ Rheumatology; ${ }^{5}$ Ophtalmology, Hospital Universitario Donostia, San Sebastián; ${ }^{6}$ Rheumatology, Hospital Can Misses, Ibiza; ${ }^{7}$ Rheumatology, Txagorritxu Hospital, Vitoria; ${ }^{8}$ Rheumatology, Hospital Universitario Infanta Elena, Madrid; ${ }^{9}$ Rheumatology, Complejo Hospitalario Universitario de Albacete, Albacete; ${ }^{10}$ Rheumatology; ${ }^{11}$ Ophtalmology, Hospital Universitario General de Castellón, Castellón, Spain

Background: Uveitis is one of the most common extra-articular manifestations of patients with spondyloarthritis $(\mathrm{SpA})$. In severe cases, uveitis may require the use of biological therapy, primarily tumor necrosis factors inhibitors (TNFi), being the most currently used infliximab and adalimumab. However, another TNFi such as certolizumab pegol (CZP), with indication for SpA patients, could be an effective option in cases of inefficacy or adverse events to other TNFi, as we have previously reported (1).

Objectives: Our objective is to analyze the effectiveness and the safety profile of CZP in patients with refractory SpA-associated-uveitis

Methods: Observational, multicentric, retrospective study. We selected all patients with a diagnosis of SpA (including ankylosing spondylitis (AS), psoriatic arthritis (PsA), non-radiographic axial SpA (nr-axSpA) and SpA associated to inflammatory bowel disease (IBD-SpA)) who had refractory uveitis (confirmed by an Ophthalmologist) as main extra-articular manifestation, and who received CZP for at least 6 months. Variables analyzed: age, sex, diagnosis, type of uveitis, duration since the first uveitis episode and number of eyes affected; previous treatment (NSAID, disease-modifying anti-rheumatic drugs (DMARDs), immunossuppressive or biological therapy); outcome, and time to follow-up.

Results: Twenty-four eyes of 13 patients (10 men); age 49.5 11.7 (range 29-71 years) were included in the study. Diagnosis were: seven AS, four PsA, one nr-axSpA, and one IBD-SpA. Type of uveitis: 9 anterior, 3 panuveitis, and

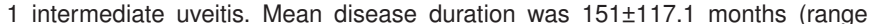
$5-420) .84 .6 \%$ patients had previously received biological therapy $(46.1 \% \geq 2$ biological agents). $61.5 \%$ received CZP in monotherapy and 5 patients received concomitant treatment: 4 methotrexate and 1 azathioprine. In all cases CZP was started due to inefficay to previous treatment except for 2 cases whose primary reason was the occurrence of adverse events (one injection site reaction and one development of relapsing polychondritis). After a follow-up of $13.1 \pm 6.6$ months (range 6-27), 9 patients are still on CZP treatment. Ten eyes showed improvement of visual acuity $(41.7 \%), 10$ remained stable and 2 worsened. During the follow-up no serious adverse events were reported. Four cases withdrew CZP treatment: 2 due to worsening of articular symptoms but with no uveitis activity; 1 due to macular edema and 1 due to uveitis activity. One patient switch to infliximab, one to golimumab, and 2 required switch to tocilizumab. In all 13 patients except 2, CZP achieved a good control of SpA activity.

Conclusions: CZP demonstrated effectiveness in patients with uveitis-associated to SpA refractory to previous TNFi treatment.

References:

[1] Llorenç V et al. Ocul Immunol Inflamm. 2016; 24: 167-72.

Disclosure of Interest: None declared

DOI: 10.1136/annrheumdis-2017-eular.4425

\section{THU0382 CHANGE IN SACROILIAC JOINT STRUCTURAL RADIOGRAPHIC DAMAGE AFTER TWO YEARS OF ETANERCEPT THERAPY IN COMPARISON TO A CONTEMPORARY CONTROL COHORT IN NON-RADIOGRAPHIC AXIAL SPONDYLOARTHRITIS}

M. Dougados ${ }^{1}$, W.P. Maksymowych ${ }^{2}$, R. Landewe ${ }^{3}$, A. Molto ${ }^{1}$,

P. Claudepierre ${ }^{4}$, M. de Hooge ${ }^{5}$, R.G. Lambert ${ }^{2}$, R. Bonin ${ }^{6}$, J.F. Bukowski ${ }^{6}$ H. Jones ${ }^{6}$, I. Logeart ${ }^{7}$, R. Pedersen ${ }^{6}$, A. Szumski ${ }^{8}$, B. Vlahos ${ }^{6}$, D. van der Heijde ${ }^{5} .{ }^{1}$ Paris Descartes University, Hôpital Cochin, Paris, France; ${ }^{2}$ University of Alberta, Edmonton, Canada; ${ }^{3}$ Amsterdam Rheumatology \& Immunology Center, Amsterdam, Netherlands; ${ }^{4}$ Universite Paris Est Creteil, Creteil, France; ${ }^{5}$ Leiden University Medical Center, Leiden, Netherlands; ${ }^{6}$ Pfizer, Collegeville, United States; ${ }^{7}$ Pfizer, Paris, France, ${ }^{8}$ InVentiv Health, Princeton, United States

Background: Despite the well-known symptomatic and anti-inflammatory effect 